\title{
LANDSCAPE OF THE MIND
}





\section{HUMAN EVOLUTION AND THE \\ ARCHAEOLOGY OF THOUGHT}

\section{JOHN F. HOFFECKER}

COLUMBIA UNIVERSITY PRESS N W YORK 


\section{Columbia University Press \\ Publishers Since 1893}

New York Chichester, West Sussex

Copyright () 2011 John F. Hoffecker

All rights reserved

\section{Library of Congress Cataloging-in-Publication Data}

Hoffecker, John F.

Landscape of the mind : human evolution and the archaeology of thought / John F. Hoffecker.

$$
\text { p. cm. }
$$

Includes bibliographical references and index.

ISBN 978-0-231-14704-0 (cloth : alk. paper)

ISBN 978-0-231-51848-2 (e-book)

1. Human evolution. 2. Brain-Evolution. 3. Thought and thinking.

$$
\text { I. Title. }
$$

$$
\begin{array}{cc}
\text { GN281.H62 } & 2011 \\
153.4-\mathrm{dc22} & 2010045026
\end{array}
$$

Columbia University Press books are printed on permanent and durable acid-free paper.

This book is printed on paper with recycled content.

Printed in the United States of America

$$
\text { c } 10987654321
$$

References to Internet Web sites (URLs) were accurate at the time of writing. Neither the author nor Columbia University Press is responsible for URLs that may have expired or changed since the manuscript was prepared. 
TO THE MAN AND HIS WORK

V. GORDON CHILDE

(1892-1957) 
